\title{
KEBIJAKAN PENGEMBANGAN KAWASAN WISATA BAHARI BERBASIS KEARIFAN LOKAL DAN PENGUATAN KELEMBAGAAN DESA DALAM RANGKA MENINGKATKAN KESEJAHTERAAN MASYARAKAT
}

\author{
Oleh \\ Yuni Ratna Sari, Dian Kagungan \\ Universitas Lampung
}

\begin{abstract}
ABSTRAK
Tujuan jangka panjang penelitian ini menghasilkan Model Pengentasan Kemiskinan Desa Pesisir Melalui Optimasi Kebijakan Pengembangan Kawasan Wisata Bahari Berbasis Kearifan Lokal dan Penguatan Kelembagaan Desa dalam rangka meningkatkan kesejahteraan masyarakat.

Kesimpulan yang diperoleh dari hasil penelitian ini adalah: (1) Kawasan Ekowisata Teluk Kiluan diwujudkan dalam bentuk pelatihan-pelatihan, konservasi penyu, serta memberikan strategi dalam promosi atau pemasarannya. Output dari kegiatan pelatihan tersebut adalah terbangunnya kesadaran bersama dalam membangun usaha dan pemasaran secara kolektif serta perlindungan lingkungan Teluk Kiluan. (2) Strategi peningkatan kapasitas kelembagaan di tingkat Desa: mendorong lembaga pekon/desa untuk memahami tugas dan fungsinya,memperkuat kelembagaan desa/pekon yang terbuka dalam arti melibatkan partisipasi masyarakat dalam setiap kegiatan pembangunan yang dilakukan. (3) Strategi pemberdayaan masyarakat pesisir melalui pengelolaan kawasan wisata Teluk Kiluan antara lain melalui pelatihanpelatihan, penanaman mangrove, terumbu karang. (4) Strategi pengelolaan wilayah pesisir melalui pengembangan ekowisata Teluk Kiluan: berusaha mendapat dukungan dari pemerintah daerah dan pusat, promosi di berbagai media sosial yang dilakukan sejak tahun 2005, dilibatkan dalam promosipromosi oleh pemerintah daerah maupun pemerintah provinsi.

Saran/rekomendasi dari hasil penelitian kami adalah: (1) Peningkatan koordinasi dan keterpaduan kebijakan dari program antar instansi terkait dalam dalam rangka pengembangan kawasan wisata Teluk Kiluan, (2) Memperkuat kelembagaan tingkat Desa/Pekon, (3) Perbaikan infrastruktur jalan menuju wilayah Teluk Kiluan dan melengkapi sarana prasarana lainnya dalam rangka mendukung kemajuan ekowisata Teluk Kiluan, (4) Pengembangan ekowisata berbasis masyarakat dengan pendampingan Lembaga Swadaya Masyarakat dan Pemerintah Daerah serta stakeholder lainnya. (5) Peningkatan kualitas Sumber
\end{abstract}


Vol. 14 No. 31 Maret 2016

Daya Manusia melalui sistem pendidikan formal maupun non formal (6) Penguatan kelembagaan desa berbasis kearifan lokal.

\section{Kata kunci: Model; pengentasan kemiskinan desa pesisir; kawasan wisata bahari; penguatan kelembagaan desa; kesejahteraan masyarakat}

\section{PENDAHULUAN}

Kawasan wisata Teluk Kiluan terletak antara 05045'54" $05048^{\prime} 00^{\prime \prime}$ LS dan 105005'06"105007'05" BT. Teluk Kiluan berada di wilayah Teluk Semaka dan sebagian besar merupakan wilayah Kabupaten Tanggamus, memiliki daerah berupa pesisir pantai hingga perbukitan, dengan luas wilayah sekitar 276,1 km atau sekitar 2.761 ha, Teluk kiluan menyimpan begitu banyak potensi keindahan alam yang sangat menarik seperti pemandangan alam yang sangat indah, ditambah lagi Teluk Kiluan sebagai salah satu kawasan habitat lumba-lumba dan berbagai spesies penyu. Hal ini seharusnya dapat dimanfaatkan sebesar-besarnya sebagai salah satu objek wisata.

Dari kajian Tim (2009) terdapat temuan bahwa kurangnya sosialisasi pada program pengembangan ekowisata Teluk Kiluan Kabupaten Tanggamus dan kurang dirasakan manfaatnya oleh masyarakat sekitar, rendahnya kualitas sumber daya manusia lokal (keterbatasan sumber daya manusia yang handal dalam pengelolaan lingkungan), infrastruktur yang buruk, seperti jalan yang buruk serta serta fasilitas penginapan yang kurang memadai, kurangnya perawatan terhadap infrastruktur yang telah tersedia, serta kurangnya perhatian atau kerja sama dengan para stakeholders.

Kunci

dari semua permasalahan tersebut di atas adalah pada pengembangan sosialisasi dan kegiatan fasilitasi kepada masyarakat kawasan Teluk Kiluan, termasuk pemilihan metode dan alat bantunya serta pada penguatan fungsi berbagai kelembagaan yang dapat melakukan kegiatan pemberdayaan masyarakat antara lain dengan berbagai kegiatan seperti, konservasi dan pengembangan usaha pariwisata berkelanjutan yang berbasiskan pada komunitas setempat, pembentukan forum masyarakat pesisir Teluk Kiluan secara terpadu dan berkelanjutan, bekerjasama dengan para stakeholders, dengan demikian kesejahteraan masyarakat setempat dapat meningkat.

\section{Tujuan Khusus}

Adapun tujuan khusus yang akan dicapai dalam penelitian ini adalah: Meningkatkan kesejahteraan masyarakat melalui penguatan fungsi berbagai kelembagaan antara lain kelembagaan desa yang dapat 
melakukan kegiatan pemberdayaan masyarakat, khususnya masyarakat pesisir di sekitar kawasan Teluk Kiluan Kabupaten Tanggamus Provinsi Lampung.

\section{METODE PENELITIAN}

Jenis penelitian ini adalah deskriptif dengan pendekatan kualitatif, Lokasi dalam penelitian ini adalah Pekon Kiluan Negeri, Kabupaten Tanggamus Provinsi Lampung. Fokus penelitian ini adalah:

1. Pengembangan Model pengentasan kemiskinan sebagai formulasi strategi yang jitu bagi kegiatan pemberdayaan masyarakat pesisir melalui kebijakan pengembangan wilayah ekowisata Teluk Kiluan

2. Kebijakan pengembangan wilayah ekowisata Teluk Kiluan berbasis kearifan lokal

3. Tujuan kebijakan pengembangan wilayah ekowisata Teluk Kiluan berbasis masyarakat

4. Ekstraksi pasal-pasal dari peraturan perundang-undangan yang dengan berkaitan pengembangan kebijakan ekowisata Teluk Kiluan berbasis masyarakat

Jenis dan Sumber Data
(1) Bupati Kepala
Daerah Kabupaten Tanggamus
(2) Kepala Dinas Pariwisata Kabupaten Tanggamus

(3) Kepala Badan Perencanaan Pembangunan Daerah Kabupaten Tanggamus

(4) Masyarakat di kawasan pesisir Teluk Kiluan (khususnya di Kecamatan Kelumbayan, tepatnya di desa Kiluan)

(5) Kepala Kecamatan Kelumbayan, Tokoh-Tokoh Masyarakat setempat dan Lembaga Pemberdayaan Masyarakat Kecamatan Kelumbayan

(7) Kepala Desa/Pekon Kiluan, Tokoh Masyarakat, Tokoh Adat, Lembaga Pemberdayaan Masyarakat Desa/Pekon Kiluan

(8) Para stakeholders yang terlibat dalam kegiatan pengembangan wilayah ekowisata Teluk Kiluan (para investor, akademisi/Perguruan Tinggi, para pemerhati lingkungan, LSM Cikal dan sebagainya).

Sebagai data sekunder, akan digunakan pula dokumen-dokumen yang berkaitan dengan substansi penelitian, antara lain UndangUndang tentang Kawasan Pesisir, surat-surat keputusan, rencana strategis Kabupaten Tanggamus, arsip-arsip, foto/dokumentasi dan dokumen-dokumen lainnya. Pengumpulan data dilakukan melalui wawancara kepada key informan, studi dokumentasi dan observasi lapang.

Teknik Analisis Data

Miles dan Huberman dalam Sugiyono (Sugiyono, 2005) mengemukakan bahwa aktivitas 
dalam analisis data dilakukan secara interaktif dan berlangsung secara terus menerus sampai tuntas sehingga datanya sudah jenuh. Dalam penelitian kualitatif, tahapan-tahapan analisis data antara lain reduksi data, penyajian data dan verifikasi/penarikan kesimpulan

Untuk menentukan keabsahan data dalam penelitian kualitatif harus memenuhi beberapa persyaratan yang dalam pemeriksaan data menggunakan 4 (empat) kriteria (Moleong, 2005) yaitu: derajat kepercayaan (credibility), keteralihan (transferability), kebergantungan (dependability), kepastian (confirmability). Untuk memeriksa kredibilitas (Moleong, 2005) maka peneliti melakukan triangulasi, dan teknik analisis kasus negatif dengan jalan mengumpulkan contoh dan kasus yang tidak sesuai dengan pola dan kecendrungan informasi yang telah dikumpulkan dan digunakan sebagai bahan pembanding (Moleong, 2005).

\section{HASIL DAN PEMBAHASAN}

1. Peran Stakeholder dalam meningkatkan

pemberdayaan masyarakat pesisir di Teluk Kiluan Kabupaten melalui Ekowisata.

1.1 Lembaga Swadaya Masyarakat Cikal
Lembaga
Swadaya

Masyarakat Cinta kepada alam
(Cikal) sebagai sebuah Lembaga Swdaya Masyarakat di Teluk Kiluan memiliki peranan dalam pemberdayaan masyarakat, yang diwujudkan melalui program pengembangan ekowisata, yang tujuannya menitikberatkan pada konservasi alam dan pengembangan usaha pariwisata berkelanjutan yang berbasiskan pada komunitas setempat, adapun peran tersebut meliputi :

1.1.1. Memberikan pelatihan pembuatan peraturan desa yang bekerjasama dengan Dinas Kelautan Provinsi Lampung.

1.1.2. Pelatihan penanaman terumbu karang.

1.1.3. Penanaman manggrove.

1.1.4. Membantu pembangunan infrastruktur sekolah .

1.1.5. Pelatihan bahasa inggris

1.1.6. Mempromosikan Teluk Kiluan dengan banyak event seperti : Kiluan Fishing Week dan ikut dalam rangkaian kegiatan Festival Krakatau.

1.1.7. Konservasi telur penyu

a. Peran dalam pemberian pendidikan dan penyadaran Langkah terpenting dalam usaha memberdayakan masyarakat adalah menumbuhkan keinginan dan motivasi dalam diri masyarakat untuk mengubah keadaan ke arah yang lebih baik. Hal ini dapat dilakukan dengan meningkatkan pendidikan. Proses pendidikan tidak hanya mentransfer 
pengetahuan, keterampilan, dan tata nilai tertentu tetapi juga berfungsi mengalokasikan peranan dengan mengantarkan subyeknya untuk menduduki posisi sosial tertentu. (Tjokrowinoto dalam Prijono dan Pranaka, 1996).

Wawancara yang kami lakukan kepada ketua Lembaga Swadaya Masyarakat Cinta Kepala Lingkungan (Cikal) pada tanggal 3 September 2013, Bapak Rico Stephanus, pada dasarnya pendidikan dapat memotivasi dan memberikan kesadaran kepada masyarakat akan potensi yang mereka miliki tidak terkecuali di Pekon Kiluan Negeri, kawasan Teluk Kiluan. Dalam kegiatan pengembangan ekowisata ini upaya pemberian pendidikan dan penyadaran telah terwujud melalui pemberian penyuluhanpenyuluhan terhadap pelestarian lingkungan seperti pelestarian lumba-lumba, penyu, transplantasi terumbu karang, larangan illegal fishing, pelatihan tour operator atau tour guide, bantuan pembangunan sarana dan prasarana sekolah serta pendidikan bahasa Inggris. Pelatihan bahasa inggris (native speaker dari English First banyak yang langsung diberikan wisatawan yang berasal dari luar negeri dengan harapan, sambil berwisata ke Teluk
Kiluan, mereka membagi ilmu pengetahuan kepada penduduk lokal setempat.

b. Peran dalam penumbuhan kelompok-kelompok basis (organisasi rakyat) atau kelompok swadaya masyarakat (KSM)

Wawancara yang kami lakukan terhadap Ketua Lembaga Swadaya Masyarakat Cinta kepada lingkungan, bahwa saat ini terdapat beberapa kelompok yang dibentuk LSM Cikal atas inisiasi Pemerintah Daerah dan stakeholder lainnya antara lain adalah:

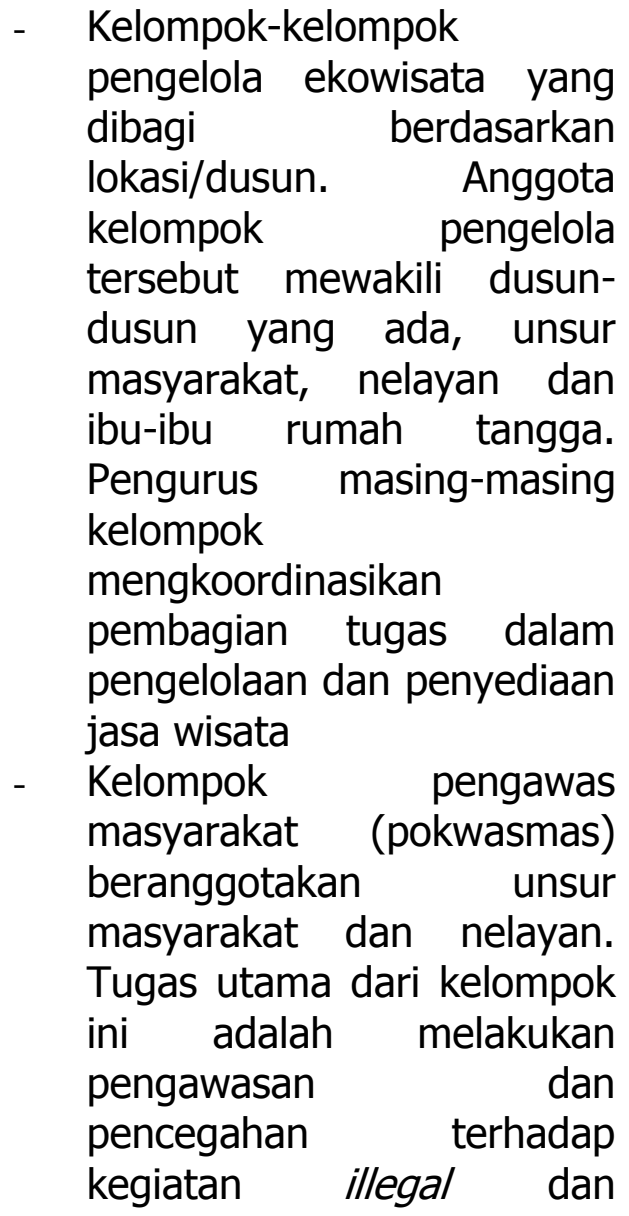


destruktif fishing. Kemudian melaporkan instansi terkait apabila ditemukan tindak pelanggaran

- Kelompok pelestari penyu "Kiluan Indah" yang salah satu kegiatannya adalah melaksanakan penangkaran penyu yang mendarat di sekitar Teluk Kiluan.

- Kelompok Sadar Wisata (Pokdarwis) Kiluan Negeri. Kelompok ini dibentuk melalui arahan Dinas Pariwisata Kabupaten Tanggamus untuk menerima dan memanfaatkan bantuan langsung masyarakat/ bantuan desa wisata dalam bentuk dana bantuan sosial kepada kelompok masyarakat di desa wisata sebagai bagian dari Program Nasional Pemberdayaan Masyarakat Mandiri

c. Peran dalam pengembangan masyarakat.

LSM Cikal beserta Pemerintah Daerah Provinsi Lampung dan Kabupaten Tanggamus melakukan upaya-upaya nyata agar masyarakat berperan aktif dalam setiap kegiatan yang diadakan. Kegiatan tersebut terbagi melalui :

- Kelompok-kelompok pengelola ekowisata yang dibagi berdasarkan lokasi/dusun. Anggota kelompok pengelola tersebut mewakili dusundusun yang ada, unsur masyarakat, nelayan dan ibu-ibu rumah tangga. Pengurus masing-masing kelompok mengkoordinasikan pembagian tugas dalam pengelolaan dan penyediaan jasa wisata

- Kelompok pengawas masyarakat (pokwasmas) beranggotakan unsur masyarakat dan nelayan. Tugas utama dari kelompok ini adalah melakukan pengawasan dan pencegahan terhadap kegiatan illegal dan destruktif fishing. Kemudian melaporkan instansi terkait apabila ditemukan tindak pelanggaran

- Kelompok pelestari penyu "Kiluan Indah" yang salah satu kegiatannya adalah melaksanakan penangkaran penyu yang mendarat di sekitar Teluk Kiluan.

- Kelompok Sadar Wisata (Pokdarwis) Kiluan Negeri. Kelompok ini dibentuk melalui arahan Dinas Pariwisata Kabupaten Tanggamus untuk menerima dan memanfaatkan bantuan langsung masyarakat/ bantuan desa wisata dalam bentuk dana bantuan sosial kepada kelompok masyarakat di desa wisata sebagai bagian dari Program Nasional Pemberdayaan Masyarakat Mandiri 
d. Peran dalam menumbuhkan infrastruktur sosial

Infrastruktur merupakan pendukung utama fungsi-fungsi sistem sosial dan ekonomi dalam kehidupan sehari-hari masyarakat. Pemberdayaan terhadap masyarakat pesisir tersebut diharapkan dapat memberikan kontribusi besar untuk membangun kemandirian masyarakat

meningkatkan bargaining position terhadap pemerintah dan pihak swasta dalam menentukan kebijakan pembangunan wilayah pesisir, memperkuat akses ekonomi politik kelembagaan sosial masyarakat beserta jaringan kerja sama dengan berbagai pihak, dan mewujudkan tata kelola pemerintahan yang baik. (Kusnadi, 2007)

Peran Lembaga Swadaya Masyarakat Cinta kepada alam dalam proses pemberdayaan memang dirasakan belum berjalan dengan optimal, dikarenakan berbagai kendala internal dan eksternal yang dihadapi. Namun keberadaan LSM Cikal di Teluk Kiluan telah membawa perubahan baik yang cukup besar bagi masyarakat. Akan tetapi LSM Cikal juga harus tetap mengembangkan perannya sebagai sebuah LSM yang berfungsi untuk memberdayakan masyarakat.
1.2 Faktor-Faktor yang menjadi kendala Lembaga Swadaya Masyarakat Cinta kepada alam dalam meningkatkan pemberdayaan masyarakat pesisir melalui pengembangan ekowisata

Secara singkat, berdasarkan hasil wawancara kami dengan narasumber, kendala utama yang dihadapi adalah :

- banyak aktivitas dari wisatawan yang kurang menjaga lingkungan

- semakin berkembangnya teluk kiluan, dan dengan banyaknya wisatawan yang berkunjung, tanah disekitar teluk kiluan menjadi mahal. Banyak menjadi minat orang membeli tanah tersebut untuk niat memperkaya pribadi.

- perilaku masyarakat dalam hal kebersihan seperti buang sampah sembarangan.

Dari hasil wawancara yang kami lakukan terhadap Kepala Pekon dan tokoh masyarakat Pekon Kiluan Negeri serta masyarakat Pekon Kiluan Negeri, di masa yang akan datang Teluk kiluan menjadi daerah ekowisata yang memenuhi prinsip-prinsip ekowisata berbasis wisata alam senantiasa menekankan pada kegiatan konservasi, menjadi pusat riset/penelitian ilmiah dan ilmu pengetahuan, Wisata berkelanjutan dan memberikan manfaat ekonomi bagi masyarakat lokal 


\subsection{Pemerintah Daerah}

$$
\text { Pemerintah daerah }
$$

Kabupaten Tanggamus telah

mengeluarkan kebijakan yang

tertuang dalam Keputusan Bupati

Tanggamus Nomor B.

243/20/12/2011 tentang Forum Gabungan Konservasi Ekosistem Teluk Kiluan Kabupaten Tanggamus dalam rangka mempertahankan dan menjaga kelestarian ekosistem Teluk Kiluan.

Selain itu Pemerintah Provinsi Lampung dan Pemerintah Kabupaten Tanggamus melalui dinas/instansi terkait berupaya mengembangkan potensi dan mengatasi permasalahan yang terjadi di Teluk Kiluan yakni dengan melaksanakan beberapa program/kegiatan antara lain:

a. Dinas Kelautan dan Perikanan Provinsi Lampung

Program/kegiatan yang dilaksanakan antara lain: pengelolaan dan pengembangangan kawasan konservasi berbasis ekowisata di Teluk Kiluan Kabupaten Tanggamus, bantuan 38 unit panel listrik tenaga surya (PLTS) dengan sistem dana bergulir, kegiatan pembinaan populasi dan habitat penyu di kawasan Teluk Kiluan, pembentukan kelompok masyarakat pengawas (pokmaswas)

b. Dinas Pariwisata dan Kebudayaan Provinsi Lampung Kegiatan pembuatan pondok sekretariat Lembaga Swadaya Masyarakat Cinta Kepada
Lingkungan (Cikal), pondok inap dan bantuan 1 unit genset.

c. Bappeda Kabupaten Tanggamus Kegiatan yang telah dilakukan Bappeda Kabupaten Tanggamus antara lain adalah telah disusunnya Studi Pengembangan Objek Wisata Teluk Kiluan dengan tema : Ekowisata berbasis bahari dan pesisir untuk rekreasi, pendidikan dan penelitian. Kegiatan yang akan dikembangkan meliputi: kegiatan wisata, penginapan, out bond, penjualan souvenir, restoran dan penangkaran satwa. Perencanaan yang dilakukan Bappeda Kabupaten Tanggamus menitikberatkan pada pembangunan infrastruktur modern.

d. Dinas Pariwisata Kebudayaan Kabupaten Tanggamus, memfasilitasi bantuan Program Nasional Pemberdayaan Masyarakat (PNPM) bidang pariwisata pada tahun 2012 dari Kementerian Kebudayaan dan Pariwisata

e. Pemerintah Desa/Pekon Kelumbayan Negeri Kecamatan Kelumbayan Kabupaten Tanggamus

Berkenaan dengan kebijakan tersebut, terdapat beberapa peraturan yang telah di hasilkan, yaitu sebagai berikut:

- Surat Keputusan Kepala Pekon Kiluan Negeri Tahun 2007 tentang Penetapan Kelompok Ekowisata 
- Surat Keputusan Kepala Pekon Kiluan Negeri Tahun 2007 tentang Keputusan Masyarakat Pekon Kiluan Negeri tentang Daerah Perlindungan Laut (DPL) Penyu

- Surat Keputusan Kepala Pekon Kiluan Negeri Tahun 2008 Tentang Tim Penggerak Wisata (Penggawa) Kiluan

- Peraturan Pekon Kiluan Negeri Tahun 2010 tentang Pengelolaan Kawasan Ekowisata Hutan, Pesisir dan Laut Pekon Kiluan Negeri \

- Peraturan Pekon Kiluan Negeri Tahun 2010 tentang Pedoman Pungutan/Retribusi Wisata

- Peraturan Kepala Pekon Kiluan Negeri Nomor 001.1/07/PKP/01.2013

Tentang Larangan
Menangkap Ikan dengan
Menggunakan
Panah/Spearfishing

\subsection{Masyarakat}

Pengembangan ekowisata di kawasan Teluk Kiluan berbasis kearifan lokal dengan melibatkan peran aktif masyarakat sejak dari perencanaan hingga pengelolaan ekowisata kawasan Teluk Kiluan dan sekitarnya.

Dalam pengelolaan kawasan ekowisata Teluk Kiluan, beberapa instansi terkait menginisiasi pembentukan kelompok-kelompok masyarakat bekerjasama dengan
Lembaga Swadaya Masyarakat Cikal dan Pemerintah Pekon Kiluan Negeri. Kelompok-kelompok tersebut meliputi :

- Kelompok-kelompok pengelola ekowisata yang dibagi berdasarkan lokasi/dusun. Anggota kelompok pengelola tersebut mewakili dusun-dusun yang ada, unsur masyarakat, nelayan dan ibu-ibu rumah tangga. Pengurus masingmasing kelompok mengkoordinasikan pembagian tugas dalam pengelolaan dan penyediaan jasa wisata

- Kelompok pengawas masyarakat (pokwasmas) beranggotakan unsur masyarakat dan nelayan. Tugas utama dari kelompok ini adalah melakukan pengawasan dan pencegahan terhadap kegiatan illegal dan destruktif fishing. Kemudian melaporkan instansi terkait apabila ditemukan tindak pelanggaran

- Kelompok pelestari penyu "Kiluan Indah" yang salah satu kegiatannya adalah melaksanakan penangkaran penyu yang mendarat di sekitar Teluk Kiluan.

- Kelompok Sadar Wisata (Pokdarwis) Kiluan Negeri. Kelompok ini dibentuk melalui arahan Dinas Pariwisata Kabupaten Tanggamus untuk menerima dan memanfaatkan bantuan langsung masyarakat/ bantuan desa wisata dalam bentuk dana bantuan sosial 
kepada kelompok masyarakat di desa wisata sebagai bagian dari Program Nasional Pemberdayaan Masyarakat Mandiri

\section{Strategi}

Kemiskinan

Pengentasan melalui Optimasi Kebijakan Pengembangan Kawasan Ekowisata Teluk Kiluan berbasis Kearifan Lokal dan Penguatan Kelembagaan Desa

2.1 Stategi Peningkatan Ekonomi Masyarakat melalui Pemanfaatan Kawasan

Ekowisata Teluk Kiluan

Kegiatan pemberdayaan masyarakat yang telah dilakukan selama ini di Teluk Kiluan dilakukan melalui :

- Pelatihan pembuatan peraturan desa yang bekerjasama dengan Dinas Kelautan Provinsi Lampung.

- Pelatihan penanaman terumbu karang.

- Penanaman mangrove.

- Membantu pembangunan infrastruktur sekolah .

- Pelatihan bahasa Inggris

- Mempromosikan Teluk Kiluan dengan banyak event seperti : Kiluan Fishing Week dan ikut dalam rangkaian kegiatan Festival Krakatau.

- Konservasi telur penyu

- Pembangunan pemondokan/cottage oleh kelompok masyarakat
- Penyewaan perahu untuk wisata lumba-lumba

2.2 Strategi pemberdayaan masyarakat pesisir melalui pengelolaan kawasan wisata Teluk Kiluan

Dari hasil studi yang kami lakukan, Lembaga Swadaya Masyarakat Cinta Kepada Lingkungan (Cikal) yang peduli terhadap pembangunan wilayah pesisir dan pengembangan ekowisata, khususnya di Teluk Kiluan, mencoba memberikan perhatian terhadap masyarakat pesisir di wilayah tersebut, untuk dapat mengembangkan potensi yang mereka miliki melalui berbagai kegiatan antara lain melalui pelatihan-pelatihan, penanaman mangrove, terumbu karang yang merupakan upaya peningkatan sumberdaya manusia dalam pengelolaan usaha yang dilakukan dengan kesadaran dan perlindungan Sumber Daya Alam yang mendukung keberlanjutan usaha masyarakat. Dengan harapan Teluk Kiluan kedepannya akan menjadi daerah ekowisata yang memenuhi priinsip-prinsip sebagai berikut:

- Berbasis wisata alam

- Menekankan pada kegiatan konservasi

- Berkaitan dengan pendidikan seperti menjadi pusat riset

- Wisata berkelanjutan

- Dapat memberikan manfaat ekonomi bagi masyarakat 
3.3 Strategi pengelolaan wilayah pesisir melalui Pengembangan Ekowisata Teluk Kiluan Upaya yang dilakukan CIKAL dalam pengembangan kawasan teluk kiluan adalah:

- Berusaha mendapat dukungan dari pemerintah daerah dan pusat

- Promosi dimedia sosial melalui situs www.telukkiluan.org, dan juga face book, twitter, dan lainlain, sejak tahun 2005.

- Dilibatkan dalam promosipromosi oleh pemda/pemprov

Kendala utama yang dihadapi

- banyak aktivitas dari wisatawan yang kurang menjaga lingkungan

- semakin berkembangnya teluk kiluan, dan dengan banyaknya wisatawan yang berkunjung, tanah disekitar teluk kiluan menjadi mahal. Banyak menjadi minat orang membeli tanah tersebut untuk niat memperkaya pribadi.

- Perilaku masyarakat dalam hal kebersihan seperti buang sampah sembarangan.

Kegiatan

Sebelum datangnya Lembaga Swadaya Masyarakat Cinta kepada alam pada tahun 2004, pengelolaan kawasan Teluk Kiluan yang berpotensi sebagai pariwisata sangat kurang diperhatikan dan dimanfaatkan oleh masyarakat setempat. Baru setelah adanya LSM
Cikal perlahan-lahan warga mulai menyadari akan pentingnya serta manfaat dari pengelolaan Teluk Kiluan. Kegiatan yang biasa dilakukan terdiri dari

1. Pemeliharaan Terumbu Karang

2. Penanaman Hutan Mangrove Kegiatan ini dikordinasikan oleh LSM Cikal beserta masyarakat sekitar diberi nama Tim Penggerak Pariwisata (TPP), yang secara Kelembagaan sudah terbentuk. Hal ini dibuktikan dengan adanya struktur dan program kerja serta sistem kerja yang telah dijalankan namun tim ini belum memiliki sekretariat secara resmi. Untuk sementara pusat kordinasi masih bertempat menumpang di Rumah Kepala desa setempat yang bernama Bpk.Kadek.

Produk hukum yang telah dihasilkan oleh Pekon Kiluan Negeri yang berkaitan dengan pengelolaaan Pariwisata di Teluk Kiluan Negeri baru berjumlah 2 Perdes (Peraturan Desa), yaitu

1. Perdes Izin Produk

2. Perdes Retribusi

Perhatian Pemerintah

Bentuk Perhatian Pemda terhadap Teluk Kiluan baru dilakukan pada tahun 2007 setelah Teluk Kiluan terkenal (booming) Sebagai tempat pariwisata yang bagus seperti Dinas kelautan Provinsi yang memberikan 10 unit perahu ketinting pada tahun 2007 dan Dinas Pertambangan yang memberikan bantuan PLTS 
(Pembangkit Listrik Tenaga Surya) ke rumah rumah warga sekitar selain dari pemerintah daerah pemerintah pusat juga turut andil dalam pemberian bantuan. Dalam hal ini dilakukan oleh Kementerian Pariwisata melalui PNPM Pariwisata yang sudah di dapat 3 kali berturut turut dengan nominal 75 juta, 100 juta dan 75 juta yang dialokasikan untuk sarana dan prasarana seperti home stay, pondokan dan MCK umum. Kementerian Dalam Negeri melalui Dirjen Pemberdayaaan Masyarakat Desa memberikan bantuan berupa bibit mangrove. Hingga saat ini Teluk Kiluan telah memiliki 15 pondok beserta home stay

Respon Masyarakat

Tanggapan masyarakat sangat positif setelah adanya manfaat dari pengelolaan pariwisata tersebut, jauh berbeda dengan sebelumnya dengan sikap mereka yang acuh akan potensi yang terpendam dari daerah tersebut .Untuk menarik antusiasme masyarakat untuk berkunjung ketempat wisata ini secara terprogram belum ada yang dilakukan secara berarti. Pernah Kegiatan yang dilakukan untuk menarik minat masyarakat dilakukan dengan kegiatan yang diinisiasi oleh LSM Cikal dengan Lomba mancing "Fishing day" yang sudah dilakukan 3 kali namun program ini terhenti dan tidak dilanjutkan karena panitia mengalami kerugian anggaran.

Kendala
Kendala-kendala yang dialami untuk pengembangan pariwisata di Teluk Kiluan selain dana yang masih minim, Penyadaran mind set atau pola pikir masyarakat yang masih belum visioner dan menanggap ini adalah tugas pemerintah sepenuhnya masih menjadi tantangan tersendiri ditambah sikap di masyarakat yang masih ada kecemburuan sosial di dalamnya

Berdasarkan uraian di atas, berikut rangkuman hasil observasi, wawancara yang kami lakukan berkenaan dengan strategi pengelolaan kawasan wisata Teluk Kiluan sesuai dengan prioritasnya :

1. Peningkatan koordinasi dan keterpaduan kebijakan dari program antar instansi terkait dalam dalam rangka pengembangan kawasan wisata Teluk Kiluan. Kebijakan tersebut perlu didukung dengan menetapkan kawasan wisata Teluk Kiluan sebagai kawasan strategis atau wisata unggulan dalam Rencana Tata Ruang Wilayah Kabupaten Tanggamus. Memperkuat kelembagaan tingkat Desa/Pekon dalam rangka pengelolaan kawasan wisata Teluk Kiluan berbasis kearifan lokal

2. Perbaikan infrastruktur jalan menuju wilayah Teluk Kiluan dan melengkapi sarana prasarana lainnya dalam rangka mendukung kemajuan ekowisata Teluk Kiluan

3. Pengembangan ekowisata berbasis masyarakat dengan 
pendampingan Lembaga

Swadaya Masyarakat dan Pemerintah Daerah serta stakeholder lainnya.

4. Pentingnya peningkatan kualitas Sumber Daya Manusia melalui sistem pendidikan formal maupun non formal melalui kegiatan pendampingan masyarakat secara kontinyu baik dalam bentuk sosialisasi, pelatihan-pelatihan dan sebagainya)

5. Penguatan kelembagaan desa berbasis kearifan lokal

\subsection{Pentingnya meningkatkan} Sumber Daya Manusia Pekon Kiluan Negeri agar proses pemberdayaan berjalan sesuai tujuan dan berkelanjutan

a. Pentingnya meningkatkan kemampuan dan pengetahuan masyarakat

Pengetahuan

bagi

masyarakat menjadi sangat penting untuk dapat dilakukan secara terus menerus. Pengetahuan ini tidak hanya berupa pendidikan formal tetapi juga pendididkan non formal. Pendidikan formal dapat dilakukan melalui pelatihan-pelatihan dan penyuluhan berdasarkan kebutuhan yang ada di masyarakat desa dalam hal ini Pekon Kiluan Negeri.

\section{b. Meningkatkan kemandirian dan kepedulian masyarakat}

Beberapa tindakan yang

harus dilakukan agar proses atau kegiatan pemberdayaan yang dilakukan tercapai sesuai tujuan yang diharapkan yaitu (i) identifikasi wakil-wakil lembaga (formal dan informal) : identifikasi dilakukan dengan cara melakukan diskusi infomal dan dengan pertemuan di dusun dengan melibatkan seluruh masyarakat serta pelaksana kelembagaan yang ada (baik formal maupun informal), dari pertemuan tersebut dihasilkan informasi tentang keterlibatan tokoh kunci dan individu-individu pada kelembagaan desa yang ada. Pelaksanan kegiatan tersebut adalah inisiator yang mengawali/bertanggungjawab mengkoordinasikan hasil-hasil yang didapat dari perencanaan desa. (ii) penyuluhan masyarakat

peningkatan kesadaran masyarakat melalui penyuluhan dan diskusi secara berkala. (iii) mengadakan kegiatan-kegiatan sosial kemasyarakatan melalui kegiatan olah raga, PKK dan pertemuanpertemuan; dengan semakin meningkatnya kesadaran masyarakat akan potensi dan kekuatan yang dimilikinya, diharapkan dapat mendorong desa dan lingkungannya untuk memanfaatkan potensi dan menjalankan kegiatan yang ada di masyarakat secara bijak. Dengan inisiasi masyarakat yang didukung oleh desa maka pengadaan fasilitasfasilitas yang dibutuhkan dalam menjalankan kegiatan dari masingmasing organisasi mudah untuk dicapai. 
2.5 Strategi peningkatan kapasitas kelembagaan di tingkat Desa (mewujudkan agar kelembagaan di desa berjalan baik)

1.mendorong lembaga pekon/desa untuk memahami tugas dan fungsinya

Pemahaman tugas dan fungsi lembaga desa satu sama lainnya akan menjadi sebuah kekuatan kolektif di tingkat desa untuk memberikan satu kontribusi bagi jalannya pembangunan desa yang lebih tertib, teratur dan bermanfaat bagi banyak orang. Upaya untuk mendorong lembaga pekon/desa dalam memahami tugas dan fungsinya perlu dilakukan melalui pertemuan-pertemuan berkala dengan melibatkan semua komponen lembaga pekon/desa dalam memajukan pekon/desa.

2.memperkuat desa/pekon yang terbuka Pembangunan pekon/desa haruslah mampu mengatur seluruh pemanfaatan sumberdaya alamnya dengan merata dan adil pada masyarakat pekon/desa yang dituangkan dalam Peraturan Pekon/Peraturan Desa (Perdes). Antara lain :

a. Peraturan Pekon Kiluan Negeri Nomor 1 Tahun 2010 Tentang Rencana Kerja Pembangunan Pekon (RKPP) Tahun Anggaran 2010

b. Peraturan Pekon Kiluan Negeri Tahun $2010 \quad$ Tentang Pengelolaan Kawasan Ekowisata
Hutan, Pesisir Dan Laut Pekon Kiluan Negeri

c. Peraturan Pekon Kiluan Negeri Tahun 2010 Tentang Pedoman Pungutan/Retribusi Wisata

Faktor keterbukaan antar semua kelompok masyarakat maupun kelompok sosial dan aparat pemerintah pekon/desa merupakan kunci keberhasilan pelaksanaan pembangunan dan pengembangan Pekon Kiluan Negeri yang mandiri.

\section{Payung Hukum yang berkaitan dengan kebijakan pengembangan wilayah ekowisata Teluk Kiluan berbasis masyarakat}

Payung hukum berkenaan dengan kebijakan pengembangan ekowisata Teluk Kiluan berbasis masyarakat antara lain adalah :

1. Peraturan Pekon Kiluan Negeri Nomor 1 Tahun 2010 Tentang Rencana Kerja Pembangunan Pekon (RKPP) Tahun Anggaran 2010

2. Peraturan Pekon Kiluan Negeri Tahun $2010 \quad$ Tentang Pengelolaan Kawasan Ekowisata Hutan, Pesisir Dan Laut Pekon Kiluan Negeri

3. Peraturan Pekon Kiluan Negeri Tahun 2010 Tentang Pedoman Pungutan/Retribusi Wisata

4. Permendagri Nomor 33 Tahun 2009 Tentang Pedoman Pengembagan Ekowisata di Daerah

5. Undang-Undang Nomor 27 Tahun 2007 Tentang 
Pengelolaan Wilayah Pesisir dan Pulau-Pulau Kecil

6. Undang-Undang Nomor 10 Tahun $2009 \quad$ Tentang Kepariwisataan

7. Undang-Undang Nomor 32 Tahun $2009 \quad$ Tentang Pengelolaan dan Perlindungan Lingkungan Hidup

\section{KESIMPULAN DAN SARAN}

Kesimpulan yang diperoleh dari hasil penelitian ini adalah:

a. Stategi Peningkatan Ekonomi Masyarakat melalui Pemanfaatan Kawasan Ekowisata Teluk Kiluan diwujudkan dalam bentuk pelatihan-pelatihan,

pembangunan infrastruktur sekolah, konservasi penyu, serta memberikan strategi dalam promosi atau pemasarannya. Output dari kegiatan pelatihan tersebut adalah terbangunnya kesadaran bersama dalam membangun usaha dan pemasaran secara kolektif serta perlindungan lingkunganTeluk Kiluan.

b. Strategi peningkatan kapasitas kelembagaan di tingkat Desa. mendorong lembaga pekon/desa untuk memahami tugas dan fungsinya,memperkuat

kelembagaan desa/pekon yang terbuka dalam arti melibatkan partisipasi masyarakat dalam setiap kegiatan pembangunan yang dilakukan

c. Strategi pemberdayaan masyarakat pesisir melalui pengelolaan kawasan wisata Teluk Kiluan antara lain melalui pelatihan-pelatihan, penanaman mangrove, terumbu karang yang merupakan upaya peningkatan sumberdaya manusia dalam pengelolaan usaha yang dilakukan dengan kesadaran dan perlindungan sumber daya alam yang mendukung keberlanjutan usaha masyarakat.

d. Strategi pengelolaan wilayah pesisir melalui pengembangan ekowisata Teluk Kiluan. Upaya yang dilakukan adalah: berusaha mendapat dukungan dari pemerintah daerah (Peran Pemerintah Daerah sangat penting sebagai fasilitator dan akselerator pembangunan suatu wilayah) dan pusat, promosi di berbagai media sosial yang dilakukan sejak tahun 2005, dilibatkan dalam promosipromosi oleh pemerintah daerah maupun pemerintah provinsi.

Saran/rekomendasi dari hasil penelitian kami di tahun pertama adalah:

a. Peningkatan koordinasi dan keterpaduan kebijakan dari program antar instansi terkait dalam dalam rangka pengembangan kawasan wisata Teluk Kiluan, perlu didukung dengan menetapkan kawasan wisata Teluk Kiluan sebagai kawasan strategis atau wisata unggulan dalam Rencana Tata 
Ruang Wilayah Kabupaten Tanggamus.

b. Memperkuat kelembagaan tingkat Desa/Pekon dalam rangka pengelolaan kawasan wisata Teluk Kiluan berbasis kearifan lokal

c. Perbaikan infrastruktur jalan menuju wilayah Teluk Kiluan dan melengkapi sarana prasarana lainnya dalam rangka mendukung kemajuan ekowisata Teluk Kiluan

d. Pengembangan ekowisata berbasis masyarakat dengan pendampingan Lembaga Swadaya Masyarakat dan Pemerintah Daerah serta stakeholder lainnya.

e. Pentingnya peningkatan kualitas Sumber Daya Manusia melalui sistem pendidikan formal maupun non formal melalui kegiatan pendampingan masyarakat secara kontinyu baik dalam bentuk sosialisasi, pelatihan-pelatihan dan sebagainya)

f. Penguatan kelembagaan desa berbasis kearifan lokal. Upaya untuk mendorong lembaga pekon/desa dalam memahami tugas dan fungsinya perlu dilakukan melalui pertemuanpertemuan berkala dengan melibatkan semua komponen lembaga pekon/desa dalam memajukan pekon/desa.

\section{DAFTAR PUSTAKA}

Moleong, L. J. (2005). Metodologi Penelitian Kualitatif. Bandung: PT. Remaja Rosdakarya.

Sugiyono. (2005). Memahami Penelitian Kualitatif. Bandung : Alfabeta. 